\title{
Groundwater quality variations in Precambrian hard rock aquifers: a case study from Kerala, India
}

\author{
P. Nandakumaran ${ }^{1}$ (D) $\cdot$ K. Balakrishnan ${ }^{1}$
}

Received: 14 February 2016 / Accepted: 15 October 2019 / Published online: 4 November 2019

(c) The Author(s) 2019

\begin{abstract}
Analytical data of groundwater samples collected from weathered and deep fractured zones in the Precambrian charnockite aquifers in Kerala, India, have been studied to understand their hydrochemical variations and reasons thereof. Concentrations of the majority of the constituents analyzed were found to increase with increasing depth of aquifers, with the exception of nitrate. Studies indicate that various processes such as ion exchange reactions, carbonate weathering and silicate weathering are active in both the aquifers which influence the hydrochemical composition of groundwater in them. The prevailing groundwater quality in the aquifers is dependent on the dominance of each process in relation to others. Principal component analysis of the data suggests that contamination from anthropogenic sources has a major role in determining the hydrochemical characteristics of groundwater in the weathered zone unlike in the case of fractured aquifers where water-rock interaction is the major factor responsible. The study also indicates limited hydraulic connection between the weathered and fractured aquifers at the local scale.
\end{abstract}

Keywords Kerala $\cdot$ Charnockites $\cdot$ Fractured aquifers $\cdot$ Groundwater quality $\cdot$ Principal component analysis

\section{Introduction}

Fractured hard rocks are important repositories of groundwater in many countries of the world. These rocks are exposed as outcrops in large areas of the world, covering more than $20 \%$ of the present land area (Krasny et al. 2003). They are highly heterogeneous and anisotropic and represent complex hydrogeological environments. In the absence of primary porosity, the storage and transport of groundwater in such rocks are facilitated through the development of secondary openings caused by weathering and fracturing. Occurrence of groundwater in hard rocks is normally confined to horizons, namely the weathered residuum, shallow fracture systems with variable degrees of hydraulic continuity with it and the deeper fractures characterized by irregular distribution of pathways of groundwater flow.

P. Nandakumaran pnkm62@gmail.com

1 Central Ground Water Board, Ministry of Water Resources, Government of India, Kerala Region, 'KEDARAM', Kesavadasapuram, Thiruvananthapuram, Kerala 695004, India
Evolution of groundwater chemistry is the result of mass transfer between interstitial water and rock-forming minerals (Zare et al. 2003). Quality of groundwater in hard rock aquifers is controlled by various factors such as climate, rainfall, lithological and geochemical characteristics of the host rock and residence time of water in contact with the aquifer material. It is often modified to a considerable extent by the prevailing land use, cropping pattern, water utilization and sanitary practices, depending on the nature and thickness of weathering and fracture pattern. Characterization of groundwater quality and a comparative study of hydrochemical characteristics of groundwater in the weathered zone and deeper fractures in the Precambrian charnockite aquifers of Kerala, India, has been attempted in this paper.

\section{Study area}

The State of Kerala, having a total geographical area of $38,863 \mathrm{~km}^{2}$, is located in the southwestern corner of India (Fig. 1). It receives average annual rainfall of about $3000 \mathrm{~mm}$ and has three distinct physiographic divisions from west to east based on topographic elevation above mean sea level (amsl), viz. coastal plains $(<7.5 \mathrm{~m}$ amsl), 
Fig. 1 Location map of study area showing sampling locations (after GSI 2005)

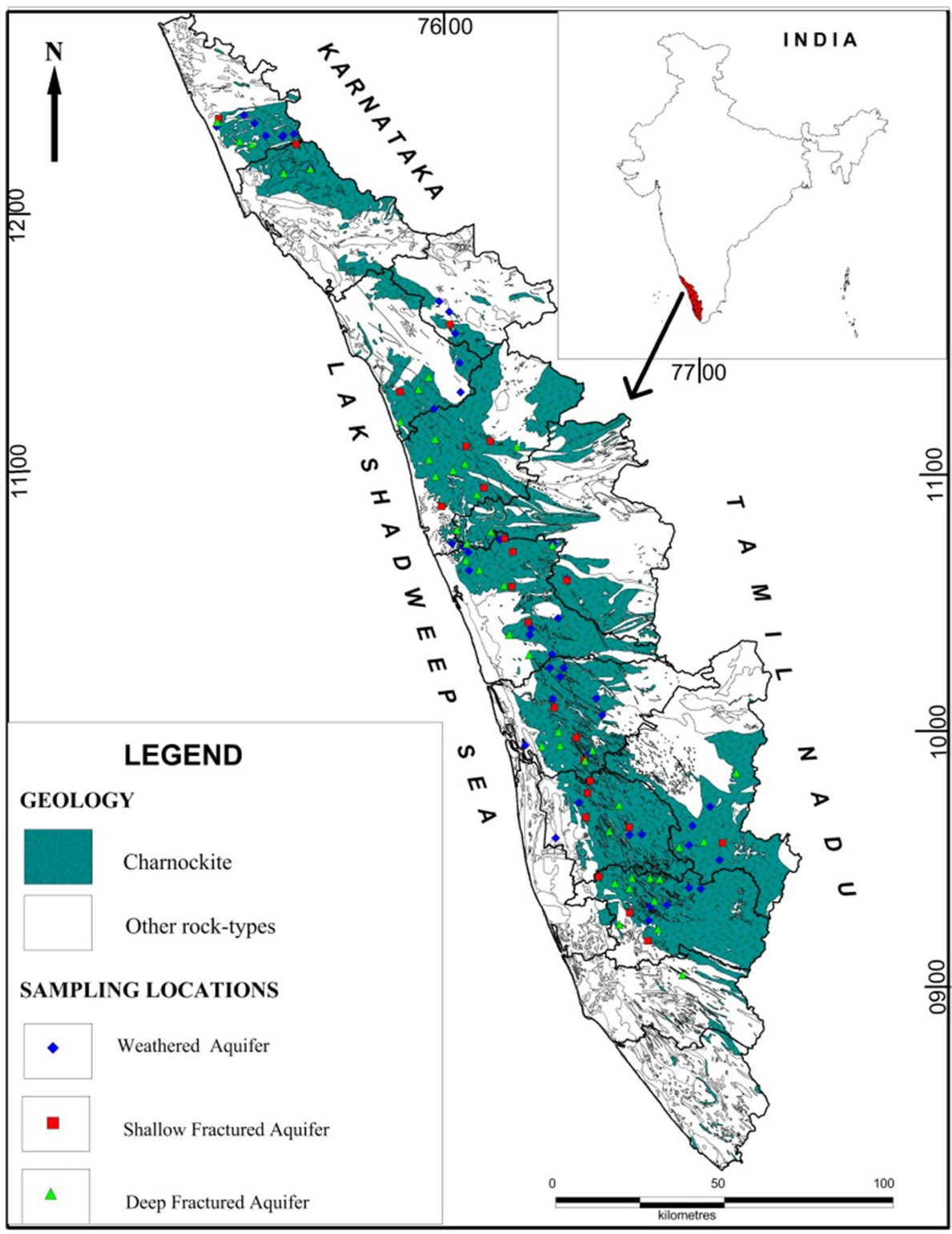

midlands (7.5-75 $\mathrm{m}$ amsl) and highlands (>75 $\mathrm{m}$ amsl) (KSCSTE 2007). The State has a population of 33.4 million as per the 2011 census and has average population density in excess of 800 (Kerala-Census 2011) against the national average of 382 . The State is also characterized by rapid urbanization, with nearly $48 \%$ of the population living in urban areas (Census of India 2011). The high population density and rapid urbanization make the State highly vulnerable to anthropogenic environmental degradation, including contamination of its water resources.

Important geological formations occurring in Kerala are Precambrian crystalline rocks, Tertiary sedimentary formations, laterites capping both hard rocks and sedimentary formations and Quaternary alluvial deposits. The Precambrian crystalline rocks include various rock assemblages such as khondalite, charnockite, gneiss and metasedimentary rocks.
Charnockites and associated gneisses constitute the most extensive hard rock formations in Kerala, occupying more than $45 \%$ of the total geographical area of the State (GSI 2005). Charnockite group of rocks shows great diversity in lithology, comprising pyroxene granulite, hornblende pyroxenite, magnetite gneisses, charnockites, hypersthene diopside gneisses and cordierite gneiss (GSI 2005). Charnockites generally consist of quartz, feldspar, biotite and pyroxenes in varying amounts, giving rise to variants ranging from felsic to intermediate types (Soman 2002). Available data indicate that charnockites of Kerala have ages ranging from 2155 and $2930 \pm 50$ ma (Soman 1997).

Charnockites are found exposed in several places in the midland and highland areas of Kerala and show considerable textural, mineralogical and geochemical variations. At many places, charnockite is found intruded by granites, dolerites 
and pegmatites. A comparison of the chemical composition of charnockites in different parts of Kerala (Soman 2002) is given in Table 1.

Data collected from the charnockite terrain in Kerala indicate a single aquifer system (Kukilaya 2007; CGWB 2012) having three aquifer zones with characteristic features. The topmost is the weathered zone, having a maximum thickness of about $15 \mathrm{~m}$ in which groundwater occurs under phreatic conditions and is extracted through large-diameter open wells. This is followed by the semi-weathered and shallow fracture zone, extending to a maximum depth of about $30 \mathrm{~m}$ in which groundwater is under phreatic or semi-confined conditions depending on the degree of its hydraulic continuity with the weathered zone. Groundwater extraction from this zone is either through deep dug wells, dug-cum-bore wells or shallow bore wells. This zone is underlain by the largely massive charnockite with an irregular fracture network in which groundwater is under semi-confined conditions, which is again hydraulically connected with the overlying aquifers on a regional scale. Groundwater levels in wells tapping all three zones behave in a similar manner with minor variations depending on the topography. Depth to water level during the pre-monsoon period in the wells tapping these aquifer zones ranges from 1 to $39 \mathrm{~m}$ depending on topographic setting and local hydrogeological conditions.

In the present study, analytical data of groundwater samples collected from wells tapping weathered and deep fractured charnockite from the entire state have been used. Samples collected from wells tapping the semi-weathered and shallow fractured zones have not been included in the study to minimize the effect of mixed waters due to their hydraulic connection with the weathered zone. The spatial extent of charnockites in Kerala and the sampling locations are shown in Fig. 1.

\section{Materials and methods}

Groundwater samples collected during various scientific investigations taken up by Central Ground Water Board (CGWB) in charnockite aquifers of Kerala were analyzed using standard norms (APHA 1995) for specific electrical conductance (EC), $\mathrm{pH}, \mathrm{Ca}, \mathrm{Mg}, \mathrm{Na}, \mathrm{K}, \mathrm{CO}_{3}, \mathrm{HCO}_{3}, \mathrm{Cl}, \mathrm{SO}_{4}$, $\mathrm{NO}_{3}$ and $\mathrm{F}$. The analytical data were first categorized into three sets on the basis of the aquifer sampled, viz. weathered zone, shallow fractured zone, with fractures within $30 \mathrm{~m}$, and deep fractured zone with fractures occurring below this depth. Analytical results of samples collected from the weathered and the deep fractured zones have been used for the study. The percent difference in cation-anion balance was then checked as per the procedure described by Brown et al. (2003). Samples having percent difference beyond the range of acceptability were discarded, and data pertaining to the remaining samples were used for the study.

In order to assess the variations in spatial distribution of various chemical parameters and constituents and to get an idea about the type of data distribution, various statistical parameters have been computed from the analytical data, which are tabulated in Table 2. Box plots of cations and anions in different aquifers are shown in Fig. 2.

The order of dominance of major cations and anions in groundwater from the aquifers was determined and is given in Table 3. The same is also graphically depicted through a Schoeller diagram (Schoeller 1962) (Fig. 3).

To determine the types of groundwater occurring in different aquifers, the analytical results have been plotted in a Piper trilinear diagram (Piper 1953) (Fig. 4). Details of samples belonging to different water types are shown in Table 4 .

A Gibbs diagram (Gibbs 1970) has been used to understand the role of various processes in determining the composition of groundwater. The plots of groundwater samples

Table 1 Chemical composition of charnockites from Kerala (wt\%) (Soman 2002)

\begin{tabular}{lcccc}
\hline Oxide & $\begin{array}{l}\text { Felsic charnockite from Cardamom } \\
\text { hills (average of 6 analyses) }\end{array}$ & $\begin{array}{l}\text { Intermediate charnockite, Carda- } \\
\text { mom hills (average of 5 analyses) }\end{array}$ & $\begin{array}{l}\text { Intermediate to felsic charnockite, } \\
\text { North Kerala (average of 14 analyses) }\end{array}$ & $\begin{array}{l}\text { Incipient } \\
\text { charnockite, } \\
\text { Ponmudi }\end{array}$ \\
\hline $\mathrm{SiO}_{2}$ & 68.8 & 58.7 & 61.22 & 65.07 \\
$\mathrm{TiO}_{2}$ & 0.79 & 1.32 & 0.79 & 0.85 \\
$\mathrm{Al}_{2} \mathrm{O}_{3}$ & 14.7 & 15.8 & 16.4 & 14.83 \\
$\mathrm{FeO}$ & 4.4 & 7.98 & 6.83 & 6.3 \\
$\mathrm{MnO}$ & 0.07 & 0.13 & 0.09 & 0.06 \\
$\mathrm{MgO}$ & 1.0 & 3.72 & 2.73 & 1.18 \\
$\mathrm{CaO}$ & 2.52 & 5.7 & 6.07 & 2.07 \\
$\mathrm{~N}_{2} \mathrm{O}$ & 3.15 & 3.79 & 3.76 & 2.46 \\
$\mathrm{~K}_{2} \mathrm{O}$ & 5.04 & 1.91 & 1.02 & 5.42 \\
$\mathrm{P}_{2} \mathrm{O}_{5}$ & 0.23 & 0.59 & 0.19 & 0.2 \\
\hline
\end{tabular}


Table 2 Statistics of chemical parameters/constituents of groundwater in charnockites of Kerala

\begin{tabular}{|c|c|c|c|c|c|c|c|c|c|c|c|c|c|}
\hline Sl. no. & Parameter/constituent & $\mathrm{pH}$ & $\mathrm{EC}(\mu \mathrm{S} / \mathrm{cm})$ & $\begin{array}{l}\mathrm{Ca} \\
(\mathrm{mg} / \mathrm{L})\end{array}$ & $\mathrm{Mg}$ & $\mathrm{Na}$ & $\mathrm{K}$ & $\mathrm{CO}_{3}$ & $\mathrm{HCO}_{3}$ & $\mathrm{Cl}$ & $\mathrm{SO}_{4}$ & $\mathrm{NO}_{3}$ & $\mathrm{~F}$ \\
\hline$A$ & \multicolumn{13}{|l|}{ Weathered zone $(N=48)$} \\
\hline 1 & Minimum & 6.5 & 31.0 & 8.0 & 1.6 & 0.5 & 1.9 & 0.2 & 0.0 & 0.0 & 2.8 & 0.0 & 0.0 \\
\hline 2 & Maximum & 9.4 & 610.0 & 42.0 & 40.0 & 58.0 & 19.0 & 19.0 & 178.0 & 119.0 & 18.0 & 46.0 & 0.7 \\
\hline 3 & Mean & 8.1 & 129.4 & 8.8 & 3.5 & 8.5 & 2.5 & 2.4 & 31.3 & 16.8 & 2.6 & 4.2 & 0.1 \\
\hline 4 & Median & 8.1 & 88.5 & 6.4 & 2.0 & 5.0 & 1.5 & 0.0 & 24.0 & 7.1 & 1.3 & 0.6 & 0.0 \\
\hline 5 & Skewness & -0.2 & 2.5 & 2.5 & 5.4 & 3.5 & 3.7 & 2.0 & 2.6 & 3.4 & 3.0 & 3.7 & 3.1 \\
\hline$B$ & \multicolumn{13}{|c|}{ Deep fracture zone $(N=43)$} \\
\hline 1 & Minimum & 7.2 & 63.0 & 2.4 & 0.5 & 1.8 & 0.0 & 0.0 & 2.4 & 2.8 & 0.0 & 0.0 & 0.0 \\
\hline 2 & Maximum & 10.1 & 875.0 & 82.0 & 23.0 & 147.0 & 5.4 & 10.0 & 251.0 & 49.0 & 180.0 & 22.0 & 1.4 \\
\hline 3 & Mean & 8.2 & 248.9 & 17.5 & 9.3 & 13.9 & 2.5 & 0.6 & 104.8 & 10.3 & 12.7 & 1.6 & 0.3 \\
\hline 4 & Median & 8.0 & 240.0 & 15.0 & 9.7 & 9.0 & 2.4 & 0.0 & 107.0 & 7.1 & 4.0 & 0.3 & 0.2 \\
\hline 5 & Skewness & 0.7 & 2.3 & 2.7 & 0.2 & 5.4 & 0.2 & 3.9 & 0.1 & 2.8 & 4.7 & 4.3 & 2.4 \\
\hline
\end{tabular}

Fig. 2 Box plots of cations and anions in groundwater in charnockites of Kerala

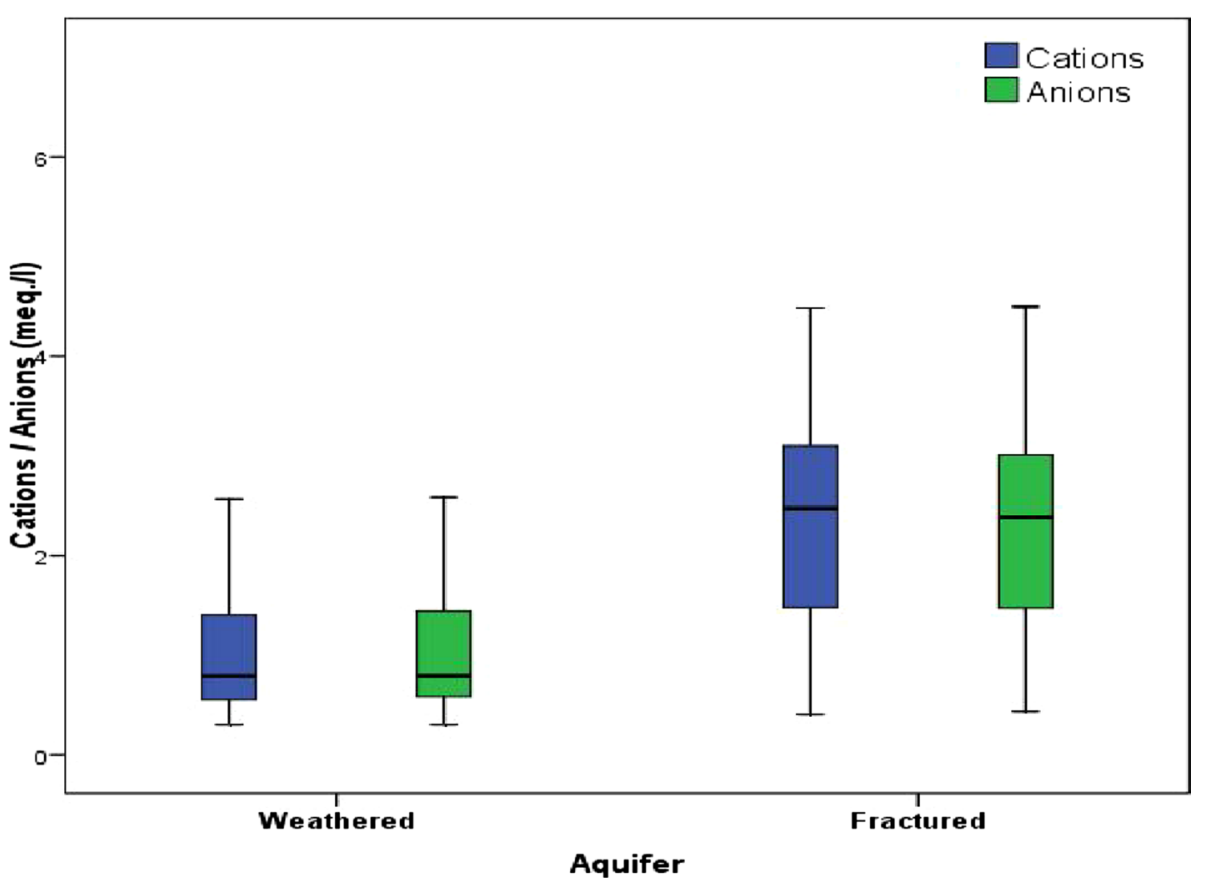

from shallow and deep fracture zones in charnockites are shown in Fig. 5.

For a comparison of major ion chemistry and the important geochemical processes taking place in the two aquifers, various ionic ratios have been studied by means of scatter plots. Plots of $\mathrm{Ca}+\mathrm{Mg}$ versus $\mathrm{HCO}_{3}+\mathrm{SO}_{4}$ (Fig. 6), $\mathrm{Ca}+\mathrm{Mg}$ versus total cations (Fig. 7), $\mathrm{Na}+\mathrm{K}$ versus total cations (Fig. 8), Na versus Ca (Fig. 9), $\mathrm{Na}$ versus $\mathrm{Cl}$ (Fig. 10), $\mathrm{Na}$ versus $\mathrm{HCO}_{3}$ (Fig. 11) and $\mathrm{Ca}+\mathrm{Mg}-\mathrm{HCO}_{3}-\mathrm{SO}_{4}$ versus $\mathrm{Na}-\mathrm{Cl}$ (Fig. 12) have been used for this purpose.

Chloro-alkaline indices (CAI) were computed as suggested by Schoeller $(1965,1967)$ for the groundwater samples to understand the base-exchange reactions in groundwater using the formulae

$\mathrm{CAI}-1=[\mathrm{Cl}-(\mathrm{Na}+\mathrm{K})] / \mathrm{Cl}$

$\mathrm{CAI}-2=[\mathrm{Cl}-(\mathrm{Na}+\mathrm{K})] /\left[\mathrm{SO}_{4}+\mathrm{HCO}_{3}+\mathrm{CO}_{3}+\mathrm{NO}_{3}\right]$

The distribution of chloro-alkaline indices in groundwater samples from all the aquifers is shown in Table 5.

The statistical technique of principal component analysis (PCA) has been used in many studies (Belkhiri et al. 2011; Chen et al. 2007; Sghaier et al. 2011; Kumar et al. 2009; Nazzal et al. 2015; Rao 2014) to understand the 
Table 3 Cation-anion dominance in groundwater in charnockite aquifers

\begin{tabular}{|c|c|c|c|c|c|}
\hline \multirow[t]{3}{*}{ S1. no. } & \multirow[t]{3}{*}{ Order of dominance } & \multicolumn{4}{|c|}{ Aquifer } \\
\hline & & \multicolumn{2}{|c|}{ Weathered } & \multicolumn{2}{|c|}{$\begin{array}{l}\text { Fractured } \\
\text { (deep) }\end{array}$} \\
\hline & & No & $\%$ & No & $\%$ \\
\hline \multicolumn{6}{|c|}{ A. Cations } \\
\hline 1 & $\mathrm{Ca}>\mathrm{Mg}>\mathrm{Na}$ & 6 & 12.5 & 16 & 37.2 \\
\hline 2 & $\mathrm{Ca}>\mathrm{Na}>\mathrm{Mg}$ & 22 & 45.8 & 6 & 14.0 \\
\hline 3 & $\mathrm{Mg}>\mathrm{Ca}>\mathrm{Na}$ & 4 & 8.3 & 14 & 32.6 \\
\hline 4 & $\mathrm{Mg}>\mathrm{Na}>\mathrm{Ca}$ & 1 & 2.1 & 1 & 2.3 \\
\hline 5 & $\mathrm{Na}>\mathrm{Ca}>\mathrm{Mg}$ & 14 & 29.2 & 4 & 9.3 \\
\hline \multirow[t]{2}{*}{6} & $\mathrm{Na}>\mathrm{Mg}>\mathrm{Ca}$ & 1 & 2.1 & 2 & 4.7 \\
\hline & & 48 & 100.0 & 43 & 100.0 \\
\hline \multicolumn{6}{|c|}{ B. Anions } \\
\hline 1 & $\mathrm{HCO}_{3}>\mathrm{Cl}>\mathrm{SO}_{4}$ & 35 & 72.9 & 34 & 79.1 \\
\hline 2 & $\mathrm{HCO}_{3}>\mathrm{SO}_{4}>\mathrm{Cl}$ & 0 & 0.0 & 6 & 14.0 \\
\hline 3 & $\mathrm{Cl}>\mathrm{HCO}_{3}>\mathrm{SO}_{4}$ & 13 & 27.1 & 2 & 4.7 \\
\hline 4 & $\mathrm{Cl}>\mathrm{SO}_{4}>\mathrm{HCO}_{3}$ & 0 & 0.0 & 0 & 0.0 \\
\hline 5 & $\mathrm{SO}_{4}>\mathrm{HCO}_{3}>\mathrm{Cl}$ & 0 & 0.0 & 1 & 2.3 \\
\hline \multirow[t]{2}{*}{6} & $\mathrm{SO}_{4}>\mathrm{Cl}>\mathrm{HCO}_{3}$ & 0 & 0.0 & 0 & 0.0 \\
\hline & & 48 & 100.0 & 43 & 100.0 \\
\hline
\end{tabular}

factors governing the hydrochemical characteristics of groundwater. The technique has been applied to the hydrochemical data with a view to summarize the statistical correlations among different chemical constituents in groundwater samples. PCA is a dimension reduction technique and synthesizes the data from a mass of variables into a set of compound axes, with the first axis explaining the most variation, then the second, and so on (Dytham 2011). By applying PCA, the constituents which contribute most to the variations in the data can be easily understood by examining weightages of the first few axes.

In the present study, PCA was applied to the analytical data of groundwater samples from the aquifers being compared. The data were normalized and standardized prior to the analysis to ascertain that they satisfy the assumption of homoscedasticity (Helsel and Hirsch 2002). The Kaiser criterion, under which only factors with eigenvalues less than or equal to 1 are extracted, was used to limit the number of factors extracted. The principal components extracted in each case were subjected to varimax rotation in order to maximize the variation among the variables under each factor. Summary of eigenvalues, variance expressed by each factor and the cumulative variance in respect of all the data sets is presented in Table 6.

The varimax-rotated PCA loading matrices in respect of the aquifers are shown in Table 7.

\section{Discussion of results}

\section{Ionic concentrations}

The chemical compositions of charnockites from different parts of Kerala (Table 1) exhibit considerable spatial variations in respect of the majority of ions. Various natural and anthropogenic influences are likely to be responsible for the spatial variations in the ionic concentrations in the groundwater from the aquifers.

A perusal of the statistics provided in Table 2 shows that the majority of the chemical parameters and ions in groundwater in the aquifers are positively skewed, with skewness often exceeding +2 , suggestive of considerable deviation from normality (George and Mallery 2010). Groundwater in both the aquifers is generally basic in nature with median
Fig. 3 Schoeller diagram showing dominance of ions in groundwater samples

\section{Schoeller Diagram}

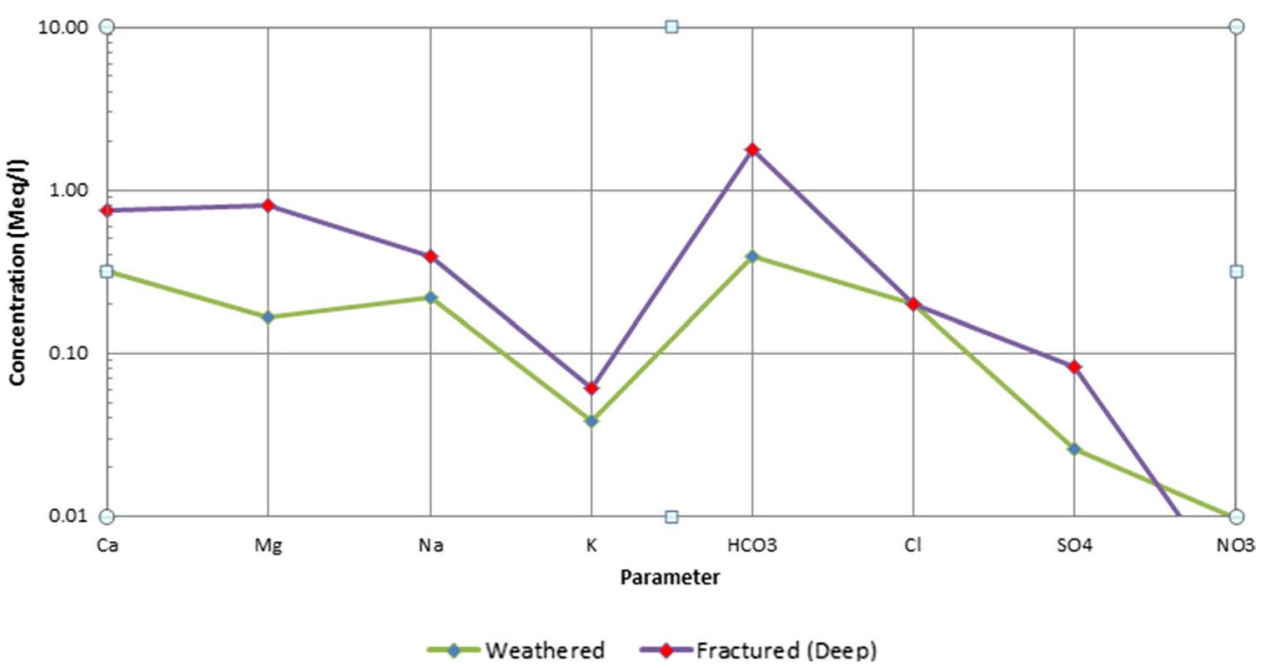




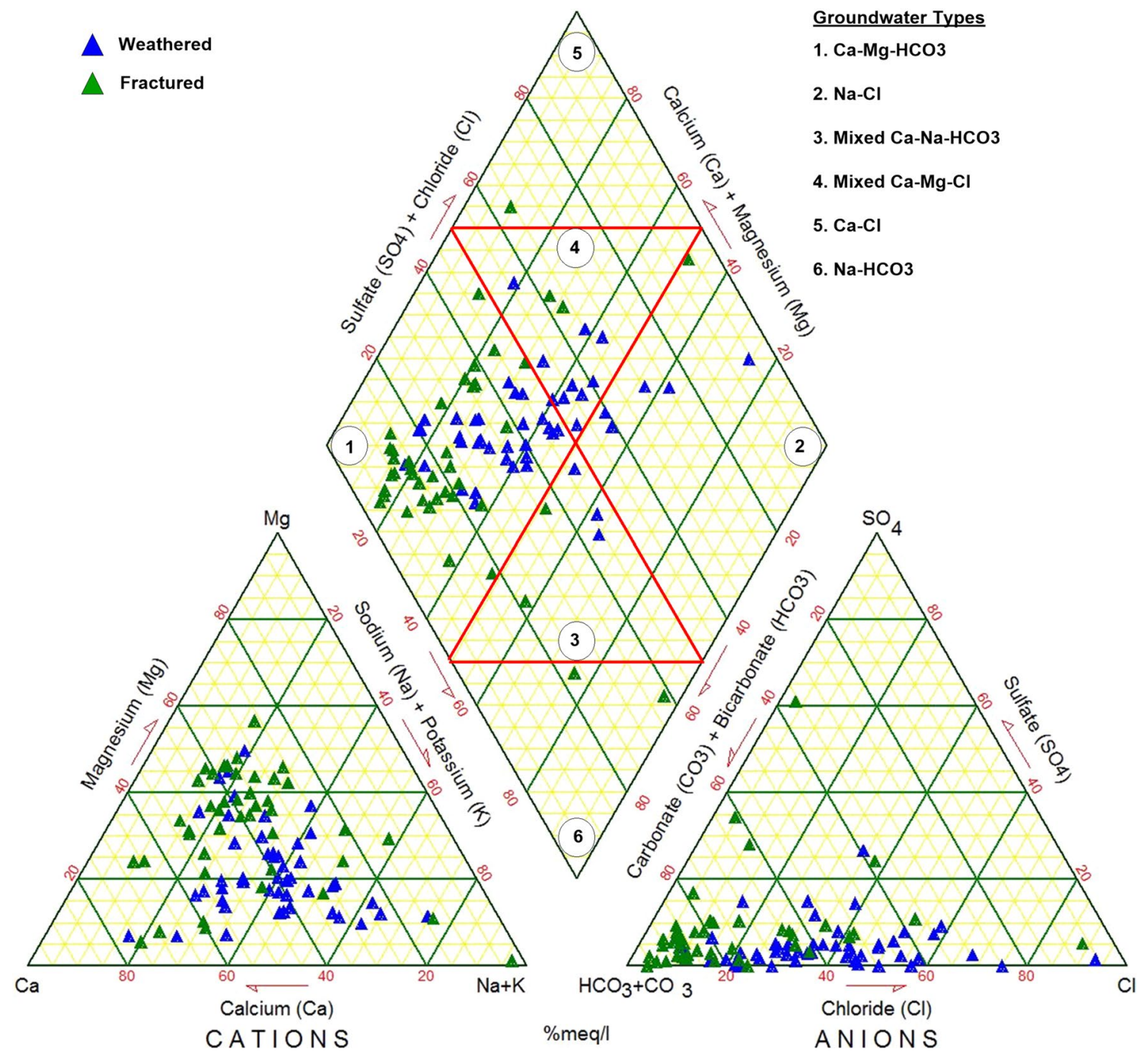

Fig. 4 Piper's trilinear diagram showing plots of groundwater samples

Table 4 Details of groundwater samples from charnockites belonging to different groundwater types

\begin{tabular}{llcc}
\hline Sl. no. & Groundwater type & \multicolumn{2}{c}{ Aquifer-wise \% of samples } \\
\cline { 3 - 4 } & & Weathered & Fractured (deep) \\
\hline 1 & $\mathrm{Ca}-\mathrm{Mg}-\mathrm{HCO}_{3}$ & 62.5 & 81.8 \\
2 & $\mathrm{Na}-\mathrm{Cl}$ & 10.4 & 2.3 \\
3 & $\mathrm{Mixed} \mathrm{Ca}-\mathrm{Na}-\mathrm{HCO}_{3}$ & 6.3 & 4.5 \\
4 & $\mathrm{Mixed} \mathrm{Ca}-\mathrm{Mg}-\mathrm{Cl}$ & 20.8 & 4.5 \\
5 & $\mathrm{Ca}-\mathrm{Cl}_{2}$ & 0.0 & 2.3 \\
6 & $\mathrm{Na}-\mathrm{HCO}_{3}$ & 0.0 & 4.5 \\
& & 100.0 & 100.0 \\
\hline
\end{tabular}

$\mathrm{pH}$ of 8.0. Groundwater in the fractured aquifers has higher median concentrations of EC and majority of ions. The only exception is $\mathrm{NO}_{3}{ }^{-}$which is has higher concentration in the weathered aquifer, due to the influence of anthropogenic contamination. Chloride is uniformly distributed in both the aquifers, showing its characteristic nature of not entering into oxidation or reduction reactions, forming no important solute complexes with other ions unless at extremely high concentrations, not forming salts of low solubility or getting adsorbed on mineral surfaces and playing few vital biochemical roles (Hem 1985). The comparison suggests higher water mineralization in deep fractured aquifers, which is also indicated by the box plots of cation and anion concentrations in the aquifers being studied.

Analysis of the dominance of ionic species (Table 3 and Fig. 3) indicates that calcium is the dominant cation in both the aquifers, followed by sodium in the weathered zone and by magnesium in the fractured zone. As far as anions are concerned, bicarbonate followed by chloride is predominant in the aquifers. Nearly $46 \%$ samples from the weathered zone have $\mathrm{Ca}>\mathrm{Na}>\mathrm{Mg}$ as the dominant cation species, followed by $\mathrm{Na}>\mathrm{Ca}>\mathrm{Mg}$ in about $29 \%$ samples. On the other 

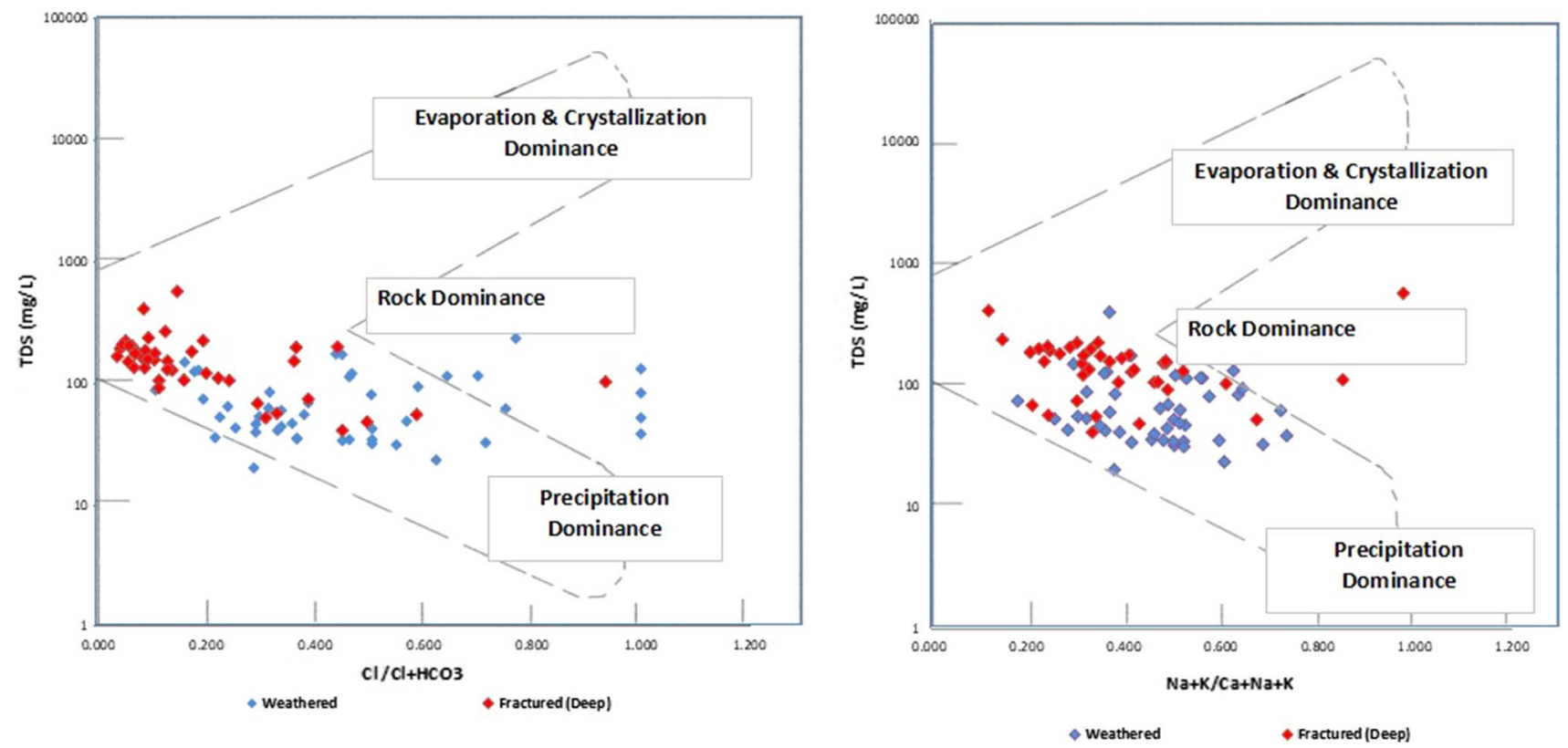

Fig. 5 Gibbs diagram showing plots of groundwater samples

Fig. 6 Plots of $\mathrm{Ca}+\mathrm{Mg}$ versus $\mathrm{HCO}_{3}+\mathrm{SO}_{4}$

Fig. 7 Plots of $\mathrm{Ca}+\mathrm{Mg}$ versus total cations
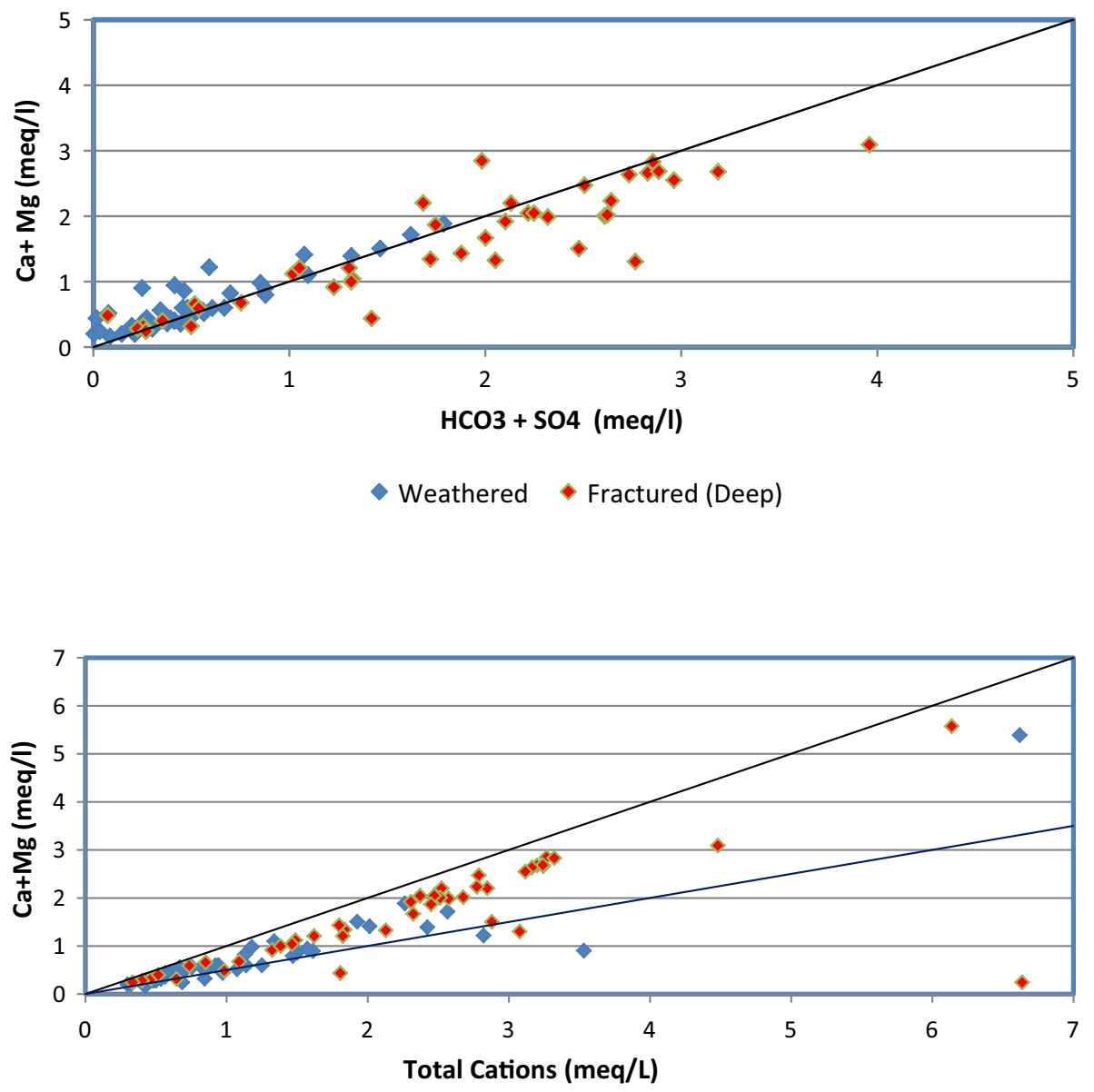

- Weathered Fractured (Deep) 
Fig. 8 Plots of $\mathrm{Na}+\mathrm{K}$ versus total cations

Fig. 9 Plots of $\mathrm{Ca}$ versus $\mathrm{Na}$

Fig. 10 Plots of $\mathrm{Na}$ versus $\mathrm{Cl}$

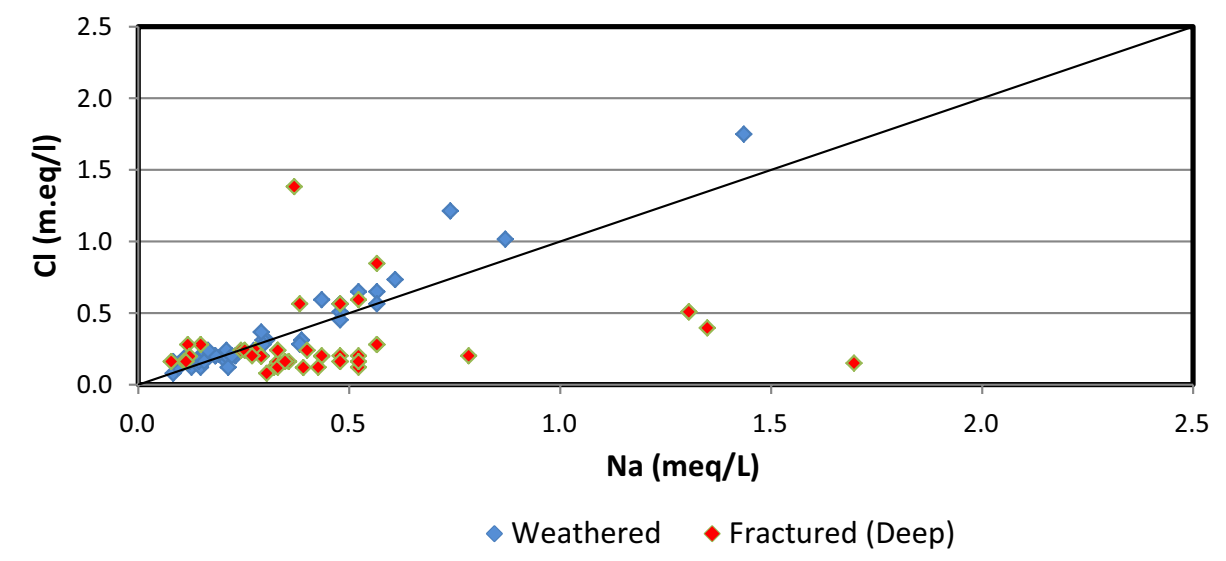

hand, the deep fractured aquifers have cation dominance in the order $\mathrm{Ca}>\mathrm{Mg}>\mathrm{Na}(37 \%)$ followed by $\mathrm{Mg}>\mathrm{Ca}>\mathrm{Na}$ $(33 \%)$, which means that the $\mathrm{Na}$ in groundwater shows a progressive reduction with increasing depth, with a concomitant increase in $\mathrm{Mg}$. A reduction in the amount of $\mathrm{Ca}$ in groundwater is also indicated when the groundwater in the deeper fractured aquifer is compared with that of the weathered zone. These variations point toward the possibility of ion exchange reactions between $\mathrm{Na}, \mathrm{Ca}$ and $\mathrm{Mg}$ in the aquifers. In the case of anions, $\mathrm{HCO}_{3}>\mathrm{Cl}>\mathrm{SO}_{4}$ is the common order of dominance in both the aquifers, followed by $\mathrm{Cl}>\mathrm{HCO}_{3}>\mathrm{SO}_{4}$ in the weathered zone and by $\mathrm{HCO}_{3}>\mathrm{SO}_{4}>\mathrm{Cl}$ in the fractured aquifers. A reduction in the $\mathrm{Cl}$ content along with an increase in $\mathrm{HCO}_{3}$ and $\mathrm{SO}_{4}$ with increasing depth of the aquifer is evident in this case, which may be indicative of the varying roles of carbonate weathering in the aquifers.

\section{Groundwater types}

Plots of analytical results of groundwater samples in Piper's trilinear diagram (Fig. 4) and classification of 
Fig. 11 Plots of Na versus $\mathrm{HCO}_{3}$

Fig. 12 Plots of $\mathrm{Ca}+\mathrm{Mg}-$ $\mathrm{HCO}_{3}-\mathrm{SO}_{4}$ versus $\mathrm{Na}-\mathrm{Cl}$

Table 5 Distribution of chloroalkaline indices in groundwater from charnockites

Table 6 Eigenvalues and variance explained by factors in PCA

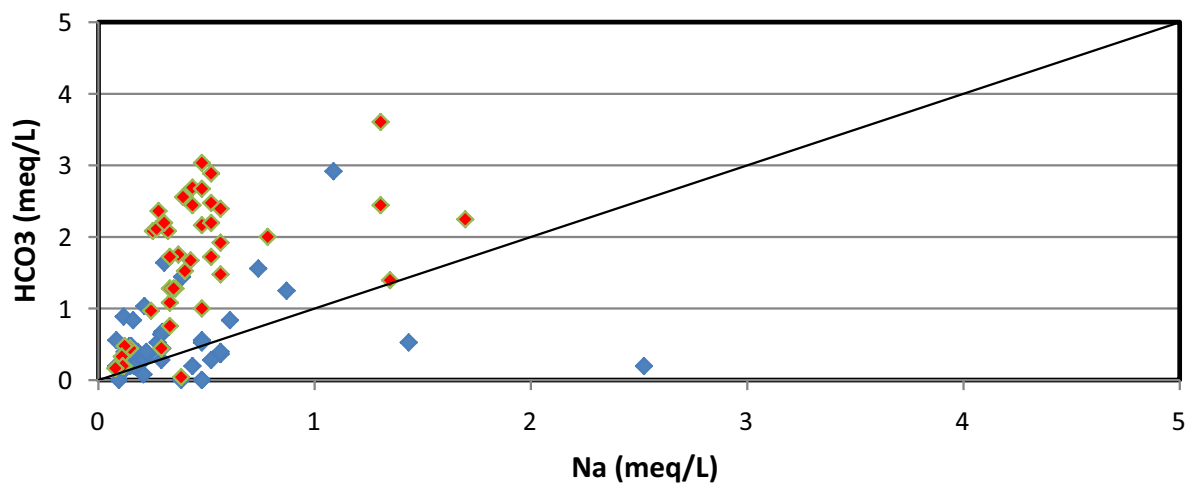

Weathered Fractured (Deep)

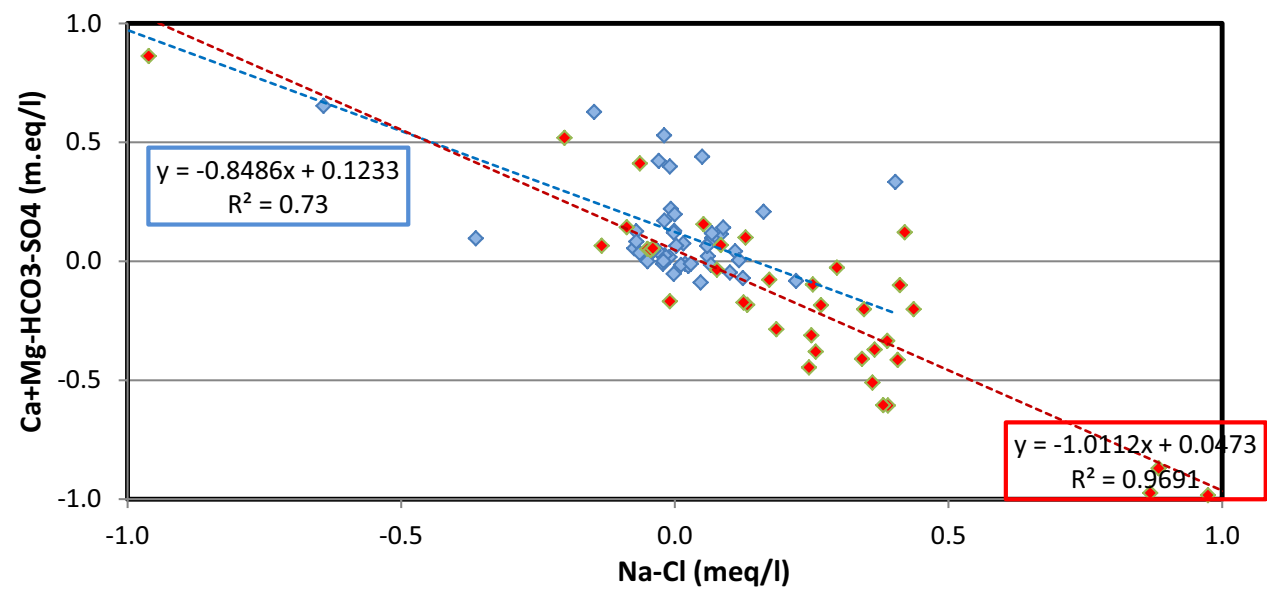

\begin{tabular}{|c|c|c|c|c|c|c|c|c|c|}
\hline \multirow[t]{2}{*}{ Sl. no. } & \multirow[t]{2}{*}{ Aquifer } & \multicolumn{3}{|c|}{ CAI - 1} & \multicolumn{3}{|c|}{ CAI - 2} & \multicolumn{2}{|c|}{$\begin{array}{l}\% \text { samples } \\
\text { with CA }\end{array}$} \\
\hline & & Min & Max & Median & Min & Max & Median & $<0$ & $>0$ \\
\hline 1 & Weathered & -2.0 & 0.6 & 0.0 & -0.4 & 2.6 & 0.0 & 47.9 & 52.1 \\
\hline 2 & Fractured (deep) & -10.9 & 0.7 & -1.39 & -1.0 & 0.5 & -0.14 & 76.7 & 23.3 \\
\hline
\end{tabular}

\begin{tabular}{llrrrr}
\hline Aquifer & Parameter & PC 1 & PC 2 & PC 3 & PC 4 \\
\hline Weathered & Initial eigenvalue & 4.584 & 1.759 & 1.094 & 1.021 \\
& Variance explained (after rotation) (\%) & 30.859 & 20.300 & 18.960 & 14.461 \\
& Cumulative variance explained (\%) & 30.859 & 51.159 & 70.119 & 84.580 \\
Fractured (deep) & 3.543 & 1.804 & 1.270 & 1.056 \\
& Initial eigenvalue & 30.187 & 21.284 & 14.500 & 10.759 \\
& Variance explained (after rotation) (\%) & 30.187 & 51.471 & 65.971 & 76.730 \\
\hline
\end{tabular}


Table 7 Varimax-rotated PCA loading matrices in respect of aquifers in charnockite

\begin{tabular}{|c|c|c|c|c|c|c|c|c|c|}
\hline \multirow[t]{3}{*}{ Sl. no. } & \multirow[t]{3}{*}{ Constituent } & \multicolumn{8}{|l|}{ Aquifer } \\
\hline & & \multicolumn{4}{|c|}{ Weathered } & \multicolumn{4}{|c|}{ Fractured (deep) } \\
\hline & & PC 1 & PC 2 & PC 3 & PC 4 & PC 1 & PC 2 & PC 3 & PC 4 \\
\hline 1 & $\mathrm{Ca}^{2+}$ & 0.594 & 0.579 & 0.397 & -0.173 & 0.409 & 0.736 & 0.020 & -0.221 \\
\hline 2 & $\mathrm{Mg}^{2+}$ & 0.647 & 0.607 & 0.120 & -0.142 & 0.518 & 0.783 & -0.029 & 0.119 \\
\hline 3 & $\mathrm{Na}^{+}$ & 0.932 & -0.023 & 0.134 & 0.119 & 0.624 & -0.292 & 0.585 & 0.126 \\
\hline 4 & $\mathrm{~K}^{+}$ & 0.409 & 0.184 & 0.787 & 0.171 & -0.184 & 0.838 & -0.006 & 0.147 \\
\hline 5 & $\mathrm{CO}_{3}^{-}$ & 0.078 & 0.048 & -0.015 & 0.898 & 0.064 & 0.073 & 0.138 & 0.878 \\
\hline 6 & $\mathrm{HCO}_{3}^{-}$ & 0.341 & 0.708 & 0.150 & -0.519 & 0.830 & 0.379 & 0.098 & 0.039 \\
\hline 7 & $\mathrm{Cl}^{-}$ & 0.946 & 0.142 & 0.085 & 0.040 & -0.076 & 0.040 & 0.857 & 0.144 \\
\hline 8 & $\mathrm{SO}_{4}{ }^{2-}$ & 0.436 & 0.368 & 0.649 & 0.060 & 0.574 & 0.070 & 0.459 & -0.345 \\
\hline 9 & $\mathrm{NO}_{3}^{-}$ & -0.256 & -0.002 & 0.790 & -0.465 & -0.788 & 0.059 & 0.356 & -0.239 \\
\hline 10 & $\mathrm{~F}$ & -0.077 & 0.796 & 0.116 & 0.234 & 0.713 & 0.159 & 0.074 & -0.076 \\
\hline
\end{tabular}

groundwater based on predominance of ions (Table 3) indicate that groundwater in both the aquifers is predominantly $\mathrm{Ca}-\mathrm{Mg}-\mathrm{HCO}_{3}$ type, with about $62 \%$ samples from the weathered aquifers and about $82 \%$ samples from the deep fractured aquifers belonging to this category. The higher percentage of samples from the fracture zones in the $\mathrm{Ca}-\mathrm{Mg}-\mathrm{HCO}_{3}$ field indicates that the groundwater in these aquifers has had too low a residence time to undergo significant rock-water interaction, though they seem to be closely connected to the weathered zone, suggesting vertical leakage. Higher percentages of $\mathrm{Na}-\mathrm{Cl}$, mixed $\mathrm{Ca}-\mathrm{Na}-\mathrm{HCO}_{3}$ and mixed $\mathrm{Ca}-\mathrm{Mg}-\mathrm{Cl}$ types of groundwater were encountered more in the phreatic aquifer when compared to fractured aquifers. These are suggestive of processes such as evapo-concentration in shallow water table areas, anthropogenic input of $\mathrm{NaCl}$ and contribution of $\mathrm{Na}$ and $\mathrm{Cl}$ originating from marine aerosols through recharging rainwater. Groundwater in the weathered zone seems to have undergone various reactions due to anthropogenic influences. The $\mathrm{Ca}-\mathrm{Mg}-\mathrm{HCO}_{3}$ type of water in this zone is being modified to mixed type (no cation dominance) and $\mathrm{Na}-\mathrm{Cl}$ type due to dissolution of salts accumulated in the soil zone by human interventions and evapo-concentration.

\section{Hydrogeochemical processes}

The prevailing hydrochemical variations in groundwater from different aquifers are, to a large extent, the net result of various hydrochemical processes active in them. These have been investigated with the help of Gibbs plot and ionic ratios in groundwater.

Plots of groundwater samples in Gibbs diagram (Fig. 5) indicate dominance of rock-water interaction as the major process controlling water chemistry. Plots of $\mathrm{HCO}_{3}+\mathrm{SO}_{4}$ $(X$-axis) versus $\mathrm{Ca}+\mathrm{Mg}(Y$-axis) in groundwater samples from the aquifers (Fig. 6) indicate different geochemical processes governing the composition of groundwater contained in them. Plots of $\mathrm{HCO}_{3}+\mathrm{SO}_{4}(X$-axis) versus $\mathrm{Ca}+\mathrm{Mg}(Y$-axis $)$ in groundwater samples are expected to be close to the 1:1 line in cases where the dissolution of calcite, dolomite and gypsum is the dominant reaction. Shifting of points to the right is indicative of ion exchange and excess $\mathrm{HCO}_{3}+\mathrm{SO}_{4}$, whereas shifting to the left is indicative of reverse ion exchange and excess $\mathrm{Ca}+\mathrm{Mg}$ (Cerling et al. 1989; Fisher and Mulican 1997). According to Datta and Tyagi (1996), samples plotting above the 1:1 line in the diagram suggest carbonate weathering, whereas those plotting below the line indicate silicate weathering. In the present study, the majority of samples (77\%) from the weathered rock aquifers have $\mathrm{Ca}+\mathrm{Mg}$ in excess of $\mathrm{HCO}_{3}+\mathrm{SO}_{4}$ and plots above the 1:1 line, whereas nearly $72 \%$ samples from the deep fractured aquifers have $\mathrm{HCO}_{3}+\mathrm{SO}_{4}$ exceeding $\mathrm{Ca}+\mathrm{Mg}$ and hence plot below the line. Going by these observations, it is likely that carbonate weathering is dominant in the weathered charnockites, whereas silicate weathering is dominant in the fractured aquifers.

Weathering products of charnockite such as montmorillonite, illite and chlorite in the aquifer are likely to be responsible for the abundance of $\mathrm{Ca}, \mathrm{Mg}$ and $\mathrm{Na}$ in groundwater in the area, as suggested by Garrels 1976 and Lakshmanan et al. (2003). As suggested by the latter, Ca may also be added to the groundwater in this zone due to the dissolution of $\mathrm{CaCO}_{3}$ and $\mathrm{CaMg}\left(\mathrm{CO}_{3}\right)_{2}$ by recharging waters. The comparatively lower concentrations of $\mathrm{Ca}+\mathrm{Mg}$ to compensate the $\mathrm{HCO}_{3}$ and $\mathrm{SO}_{4}$ in groundwater in the deeper zone may indicate the absence or non-significance of these reactions in fractured aquifers.

Plots of $\mathrm{Ca}+\mathrm{Mg}$ versus total cations $(\mathrm{TZ}+)$ in groundwater samples (Fig. 7) show that the majority of samples from both the aquifers lie well below the 1:1 line, suggesting a larger contribution of alkalis $(\mathrm{Na}+\mathrm{K})$ to the $\mathrm{TZ}+$ when compared to alkaline earth metals $(\mathrm{Ca}+\mathrm{Mg})$. However, the 
linear pattern of the plotted points between lines representing 1:1 and 1:0.5 ratios of $\mathrm{Ca}+\mathrm{Mg}$ and $\mathrm{TZ}+$ also indicates that weathering of silicate minerals may be responsible for some of the $\mathrm{Ca}$ and $\mathrm{Mg}$ ions in the groundwater from both the aquifers (Kumar et al. 2009).

The role of silicate weathering in the contribution of cations to groundwater was further investigated using the $(\mathrm{Na}+\mathrm{K}$ )/total cations index (Sarin et al. 1989; Lakshmanan et al. 2003). The scatter plots of $\mathrm{Na}+\mathrm{K}$ versus total cations $(\mathrm{TZ}+)($ Fig. 8) show the majority of points along and below the $\mathrm{Na}+\mathrm{K}=0.33 \mathrm{TZ}+$ line, suggesting silicate weathering as an important geochemical process contributing cations to the groundwater. The reduction in the proportion of $\mathrm{Na}+\mathrm{K}$ below the stipulated $50 \%$ of $\mathrm{TZ}+$ indicating silicate weathering as observed by Datta and Tyagi (1996) may be attributed to the $\mathrm{Ca} / \mathrm{Na}$ exchange process taking place in the aquifers. The scatter plots of $\mathrm{Ca}$ versus $\mathrm{Na}$ (Fig. 9) which shows that about $67 \%$ and $84 \%$ samples from the weathered zone and deep fractured zone, respectively, have $\mathrm{Ca}$ in excess of $\mathrm{Na}$ and hence plots above the 1:1 line, indicating $\mathrm{Ca}-\mathrm{Na}$ ion exchange as a mechanism for the increase in $\mathrm{Ca}$ in groundwater, more so in the fractured aquifers.

The $\mathrm{Na}-\mathrm{Cl}$ scatter diagram (Fig. 10) and comparison of $\mathrm{Na}$ and $\mathrm{Cl}$ ions in groundwater show that $\mathrm{Cl}$ exceeds $\mathrm{Na}$ in about 69\% samples from the weathered aquifers and plot above the 1:1 line, whereas $\mathrm{Na}$ exceeds $\mathrm{Cl}$ in about $74 \%$ samples from the deep fractured aquifers, resulting in the majority of $\mathrm{Na}-\mathrm{Cl}$ plots below the line. The low content of $\mathrm{Na}$ compared to $\mathrm{Cl}$ is suggestive of the absence of halite dissolution and absence of significant silicate weathering in the weathered aquifer. On the other hand, excess $\mathrm{Na}$ over $\mathrm{Cl}$ indicates the major role of silicate weathering in controlling the hydrochemistry of fractured aquifers. Though the predominance of $\mathrm{HCO}_{3}$ over $\mathrm{Na}$ (Fig. 11) in about $75 \%$ samples from the weathered zone may suggest some amount of silicate weathering in this zone as well (Fisher and Mulican 1997), the comparatively low $\mathrm{Na}$ in the weathered aquifer in spite of this process as well as anthropogenic and marine aerosol inputs implies ion exchange between $\mathrm{Na}$ and $\mathrm{Ca}$, causing reduction of $\mathrm{Na}$ in groundwater (Lakshmanan et al. 2003), which is also supported by the scatter plots of $\mathrm{Na}$ versus Ca shown in Fig. 8.

The scatter plots of $\mathrm{Na}-\mathrm{Cl}$ versus $\mathrm{Ca}+\mathrm{Mg}-\mathrm{HCO}_{3}-\mathrm{SO}_{4}$, along with trend lines and regression equations for different aquifers, are shown in Fig. 12. In these plots, $\mathrm{Na}-\mathrm{Cl}(\mathrm{m}$ eq/l) represents the amount of $\mathrm{Na}$ gained or lost relative to that provided the halite dissolution, whereas $\mathrm{Ca}+\mathrm{Mg}-\mathrm{HCO}_{3}$ ( $\mathrm{m} \mathrm{eq} / \mathrm{l}$ ) represents the amount of $\mathrm{Ca}$ and $\mathrm{Mg}$ gained or lost relative to that provided by gypsum, calcite and dolomite dissolution (Ramesh 2007). The groundwater samples are expected to fall along a line with a slope of -1 if ion exchange is the dominant process in the system (Rajmohan and Elango 2003). In the present case, the lines fitted through the plotted points have slopes of -0.8486 for the weathered zone and -1.0112 for the deep fractured zone respectively, indicating that reverse ion exchange has an important role in determining the $\mathrm{Ca}, \mathrm{Mg}$ and $\mathrm{Na}$ contents in groundwater in both the aquifers and more so in the fractured ones.

Chloro-alkaline indices have been used by many workers (Ramesh 2007; Ishaku et al. 2011; Odukoya et al. 2013; Mohammed and Zineb 2015) to understand the direction in which ion exchange reactions proceed. When there is an ion exchange between $\mathrm{Na}$ and $\mathrm{K}$ in groundwater with $\mathrm{Mg}$ or $\mathrm{Ca}$ in the aquifer material (rock/weathered layer), both of the indices are positive, indicating ion exchange of sodium in groundwater with calcium or magnesium in the weathered material, whereas in reverse ion exchange both indices are negative, indicating exchange of $\mathrm{Mg}$ or $\mathrm{Ca}$ in the groundwater with $\mathrm{Na}$ and $\mathrm{K}$ in the rocks (Ramesh 2007). The chloroalkaline indices computed for the present study (Table 5) indicate that both the indices are negative in the majority of samples from fractured aquifers, suggesting predominance of reverse ion exchange in these aquifers. In the samples from the weathered aquifers, nearly $50 \%$ samples each have the positive and negative indices, indicating that both ion exchange and reverse ion exchange are active in this aquifer.

\section{Factors controlling the hydrochemistry of groundwater}

The principal component analysis (PCA) of the hydrochemical data indicates that four principal components each account respectively for 84.6 and $76.7 \%$ of the hydrochemical variations in weathered and deep fracture zones (Table 6). The matrices of varimax-rotated loadings of the principal components given in Table 7 show that groundwater in the weathered zone has the highest positive loadings of $\mathrm{Cl}$ and $\mathrm{Na}$ along $\mathrm{PC} 1$, followed by $\mathrm{F}$ and $\mathrm{HCO}_{3}$ along $\mathrm{PC}$, $\mathrm{NO}_{3}$ and $\mathrm{K}$ along $\mathrm{PC} 3$ and $\mathrm{CO}_{3}$ along $\mathrm{PC} 4$. The deep fractured aquifers have high positive loadings of $\mathrm{HCO}_{3}$ and $\mathrm{Na}$ along $\mathrm{PC} 1$, followed by $\mathrm{K}, \mathrm{Mg}$ and $\mathrm{Ca}$ along $\mathrm{PC} 2, \mathrm{Cl}$ along $\mathrm{PC} 3$ and $\mathrm{CO}_{3}$ along PC4.

The distribution of chemical components with high positive loadings in the weathered zone suggests the role of anthropogenic activities in determining the hydrochemistry of groundwater in this zone. The high positive loadings of $\mathrm{Na}$ and $\mathrm{Cl}$ are likely due to the anthropogenic input of sodium chloride into the environment and marine aerosols carried by rainwater, with $\mathrm{Na}$ being supplemented to some extent by silicate weathering and reverse ion exchange reaction in the aquifer. The $\mathrm{HCO}_{3}$ constituting the major component of PC2 in this zone is the result of water-rock interaction, whereas domestic sewerage and chemical fertilizers are likely to be the major sources of $\mathrm{NO}_{3}$ and $\mathrm{K}$ respectively, making up the PC3. Degradation of organic material is likely 
to be the major source of $\mathrm{CO}_{3}$, which constitute the major share of PC4 in this zone.

In the fractured aquifers, water-rock interaction appears to be the major process controlling the groundwater chemistry, as indicated by constituents of PC 1 and PC 2 such as $\mathrm{Ca}$, $\mathrm{HCO}_{3}, \mathrm{Mg}, \mathrm{Na}$ and $\mathrm{F}$. The presence of $\mathrm{Na}$ in $\mathrm{PC} 1$ is likely to be due to the predominance of silicate weathering and reverse ion exchange reactions and consequent $\mathrm{Na}$ enrichment in the aquifers and not from anthropogenic sources, as they, to a large extent, are isolated from the overlying weathered aquifer. The conspicuous absence of $\mathrm{NO}_{3}$ in any of the principal components also indicates the absence of significant anthropogenic contamination in this aquifer.

\section{Conclusions}

Based on the detailed study of hydrochemical data of groundwater samples collected from the weathered and fractured aquifers in the Precambrian charnockite aquifers in Kerala, India, it is observed that groundwater in both the aquifers is generally basic in nature and frequency distributions of the majority of constituents are positively skewed with significant deviation from normality. Fractured aquifers, in general, have groundwater with higher concentrations of chemical constituents with the notable exception of $\mathrm{NO}_{3}$, indicating the absence of anthropogenic contamination. Study of cation dominance in the aquifers indicates more $\mathrm{Na}$ in weathered zone when compared to the fractured aquifers, likely to be due to factors such as anthropogenic input of common salt $(\mathrm{NaCl})$ into the groundwater system, contribution from marine aerosols and reverse ion exchange reactions between $\mathrm{Ca}$ in groundwater with $\mathrm{Na}$ in the aquifer material. Distribution of anions similarly indicates a reduction in $\mathrm{Cl}$ with increasing depth, together with an increase in $\mathrm{HCO}_{3}+\mathrm{SO}_{4}$, indicative of ion exchange process and lack of supply of anthropogenic input of $\mathrm{Cl}$ in the fractured aquifers. Plots of groundwater samples in Piper's trilinear diagram suggest evapo-concentration, reverse ion exchange and natu$\mathrm{ral} /$ anthropogenic input of $\mathrm{NaCl}$ in the weathered aquifers, resulting in comparatively higher percentage of samples belonging to $\mathrm{Na}-\mathrm{Cl}, \mathrm{Ca}-\mathrm{Na}-\mathrm{HCO}_{3}$ and mixed $\mathrm{Ca}-\mathrm{Mg}-\mathrm{Cl}$ types of groundwater in this zone.

Comparison of the predominance of various hydrochemical processes in the aquifers using ionic ratios and chloroalkaline indices indicates that various processes such as ion exchange, reverse ion exchange, carbonate weathering and silicate weathering are active in the aquifers and the relative importance of each in comparison to the others has resulted in the characteristically different hydrochemical compositions of groundwater in them. While ion exchange, reverse ion exchange and carbonate weathering are active in the weathered zone, reverse ion exchange and silicate weathering appear to be dominant in the fractured aquifers. Results of the principal component analysis of the hydrochemical data of groundwater suggest that anthropogenic activities have an important role in determining the hydrochemistry of groundwater in the weathered zone together with rock-water interaction, which appears to have a predominant role in the evolution of the hydrochemistry of groundwater in the fractured zone. The differences in the hydrochemical characteristics of groundwater in the aquifers also indicate limited interconnection between them at the local scale, which has prevented the evolution of groundwater having homogenized hydrochemical characteristics in both the aquifer systems.

Acknowledgements The authors are thankful to Shri K.B. Biswas, Chairman, Central Ground Water Board, Ministry of Water Resources, River Development and Ganga Rejuvenation, Government of India, for encouragement and for granting permission for publication of this paper and to Shri G.C. Pati, Member (TT\&WQ), Central Ground Water Board for scrutiny and suggestions. They thank all the scientific officers of Central Ground Water Board, Kerala Region, Trivandrum, who were involved in the collection of groundwater samples during various scientific investigations and are also thankful to Smt. V.N. Sreelatha and Smt. Bindu J Viju for analysis of the groundwater samples and for the fruitful discussions during the preparation of the paper. The anonymous reviewers are thanked for their meticulous reviews, which have helped improve the quality of the paper.

Open Access This article is distributed under the terms of the Creative Commons Attribution 4.0 International License (http://creativeco mmons.org/licenses/by/4.0/), which permits unrestricted use, distribution, and reproduction in any medium, provided you give appropriate credit to the original author(s) and the source, provide a link to the Creative Commons license, and indicate if changes were made.

\section{References}

APHA (1995) Standard methods for the examination of water and wastewater, 17th edn. APHA, Washington DC

Belkhiri L, Boudoukha A, Mouni L (2011) A multivariate statistical analysis of groundwater chemistry data. Int J Environ Res 5(2):537-544

Brown AG, Pustay EA, Gibbs J (2003) Methods for water qualityassurance review of water-quality data in New Jersey. U.S Geological Survey Open-file report 02-383, West Trenton, New Jersey

Census of India (2011) Provisional population totals; Paper 2 of 2011: Kerala. http://censusindia.gov.in/2011-prov-results/paper2/prov_ results_paper2_kerala.html. Accessed 1 Sept 2015

Central Ground Water Board (2012) Aquifer systems of Kerala; Unpublished report of CGWB, Ministry of Water Resources, Government of India

Cerling TE, Pederson BL, Damm KLV (1989) Sodium-calcium ion exchange in the weathering of shales: implications for global weathering budgets. Geology 17:552-554

Chen K, Jiao JJ, Huang J, Huang R (2007) Multivariate statistical evaluation of trace elements in groundwater in a coastal area in Shenzhen, China. Environ Pollut 147:771-780 
Datta PS, Tyagi SK (1996) Major ion chemistry of groundwater in Delhi area: chemical weathering processes and groundwater flow regime. J Geol Soc India 47:179-188

Dytham C (2011) Choosing and using statistics: a Biologist's guide, 3rd edn. Wiley, Hoboken

Fisher RS, Mulican WF (1997) Hydrochemical evolution of sodiumsulfate and sodium-chloride groundwater beneath the Northern Chihuahuan desert, Trans-Pecos, Texas, USA. Hydrogeol J 10(4):455-474

Garrels RM (1976) A survey of low temperature water mineral relations. In: Interpretation of environmental isotope and hydrogeochemical data in groundwater hydrology. International Atomic Energy Agency, Vienna, pp 65-84

George D, Mallery P (2010) SPSS for Windows step by step: a simple guide and reference, 18.0 update. Prentice Hall, Boston, MA

Gibbs RJ (1970) Mechanisms controlling world water chemistry. Science 170:1088-1090. https://doi.org/10.1126/scien ce. 170.3962 .1088

GSI (Geological Survey of India) (2005) Geology and mineral resources of the States of India; Part IX-Kerala. Miscellaneous Publication No. 30

Helsel DR, Hirsch RM (2002) Statistical methods in water resources. USGS Techniques of water resource investigations, Book 4, Chapt. A3. http://water.usgs.gov/pubs/twri/twri4a3/. Accessed 10 Feb 2016

Hem JD (1985) Study and interpretation of the chemical characteristics of natural water, 3rd edn. U.S Geological Survey Water-Supply Paper 2254, p 263

Ishaku JM, Ahmed AS, Abubakar MA (2011) Assessment of groundwater quality using chemical indices and GIS mapping in Jada area, Northeastern Nigeria. J Earth Sci Geotech Eng 1(1):35-60

Kerala-Census (2011) http://www.census2011.co.in/census/state/keral a.html. Accessed 1 Sept 2015

Krasny J, Hrkal Z, Bruthans J (2003) Proceedings of the international conference on groundwater in fractured rocks. Extended abstracts IHP-VI, Series on groundwater No. 7

KSCSTE (Kerala State Council for Science, Technology and Environment) (2007) State of the environment report of Kerala 2007, vol 1

Kukilaya JP (2007) Characteristic responses to pumping in hard rock fracture aquifers of Thrissur, Kerala, and their hydrogeological significance. J Geol Soc India 69(5):1055-1066

Kumar M, Kumari K, Singh UK, Ramanathan AL (2009) Hydrogeochemical processes in the groundwater environment of Muktsar, Punjab: conventional graphical and multivariate statistical approach. Environ Geol 57:873-884

Lakshmanan E, Kannan R, Senthil Kumar M (2003) Major ion chemistry and identification of hydrogeochemical processes of ground water in a part of Kancheepuram district, Tamil Nadu, India. Environ Geosci 10(4):157-166

Mohammed C, Zineb A (2015) Geochemistry and hydrogeochemical process of groundwater in the Souf valley of low septentrional Sahara, Algeria. Afr J Environ Sci Technol 9(3):261-273. https ://doi.org/10.5897/AJEST2014.1710
Nazzal Y, Zaidi FK, Ahmed I, Ghrefat H, Naeem M, Al-Arifi NSN, Al-Shaltoni SA, Al-Kahtany KM (2015) The combination of principal component analysis and geostatistics as a technique in assessment of groundwater hydrochemistry in arid environment. Curr Sci 108(6):1138-1145

Odukoya AM, Folorunso AF, Ayolabi EA, Adeniran EA (2013) Groundwater quality and identification of hydrogeochemical processes within university of Lagos, Nigeria. J Water Resour Prot 5:930-940

Piper AM (1953) A graphic procedure in the interpretation of water analyses. U.S. Geol. Survey Ground Water Note, No. 12

Rajmohan N, Elango L (2003) Identification and evolution of hydrogeochemical processes in the groundwater environment in an area of the Palar and Cheyyar River Basins, Southern India. Environ Geol 46:47-61. https://doi.org/10.1007/s00254-004-1012-5

Ramesh K (2007) Hydrochemical studies and effect of irrigation on groundwater quality in Tondiar basin, Tamil Nadu. Ph.D. Thesis, Faculty of Civil Engineering; Anna University, Chennai, Tamil Nadu. http://hdl.handle.net/10603/26395. Accessed 30 Aug 2015

Rao S (2014) Spatial control of groundwater contamination, using principal component analysis. J Earth Syst Sci 123(4):715-728

Sarin MM, Krishnaswamy S, Dilli K, Somayajulu BLK, Moore WS (1989) Major ion chemistry of the Ganga-Brahmaputra river system: weathering processes and fluxes to the Bay of Bengal. Geochim Cosmochim Acta 53:997-1009

Schoeller H (1962) Les eaux souterraines. Masson, Paris, p 642

Schoeller H (1965) Qualitative evaluation of groundwater resources. In: Methods and techniques of groundwater investigations and development. UNESCO, pp 54-83

Schoeller H (1967) Geochemistry of groundwater. An international guide for research and practice. UNESCO 15(1967):1-18

Sghaier K, Barhoumi H, Maaref A, Siadat M, Renault NJ (2011) Characterization and classification of groundwater from wells using an electronic tongue (Kairouan, Tunisia). J Water Resour Prot 3:531-539

Soman K (1997) Geology of Kerala. Geological Society of India, Bangalore

Soman K (2002) Geology of Kerala, 2nd edn. Geological Society of India, Bangalore

Zare M, Raeisi E, Jaffar H, Moore F (2003) Hydrochemistry of the Shir-kuh granitoid hard-rock aquifer, Iran. Part 1: Spatial and temporal variations. In: Proceedings of the international conference on groundwater in fractured rocks; Extended abstracts. IHP-VI, Series on groundwater No. 7, pp 229-230

Publisher's Note Springer Nature remains neutral with regard to jurisdictional claims in published maps and institutional affiliations. 